\title{
A magyar tüdőtranszplantációs program indulása és első eredményei
}

\author{
Gieszer Balázs dr. ${ }^{1,3}$ - Radeczky Péter dr. ${ }^{1,3}$ - Ghimessy Áron dr. ${ }^{1,3}$ \\ Farkas Attila dr. ${ }^{1,3}$. Csende Kristóf dr. ${ }^{1}$ - Bogyó Levente dr. ${ }^{1,3}$ \\ Fazekas Levente dr. ${ }^{3,4}$. Kovács Nóra ${ }^{3}$ - Madurka Ildikó dr. ${ }^{2}$ \\ Kocsis Ákos dr. ${ }^{1,3}$ - Agócs László dr., ${ }^{1,3}$ - Török Klára dr., ${ }^{1,3}$ \\ Bartók Tibor dr. ${ }^{2}$ - Dancs Tamás $\mathrm{dr}^{2}{ }^{2}$ - Schönauer Nóra dr. ${ }^{2}$ \\ Tóth Krisztina dr. ${ }^{2}$ - Szabó József $\mathrm{dr}^{7}{ }^{7}$ Eszes Noémi dr. ${ }^{5}$ \\ Bohács Anikó dr. ${ }^{5}$. Czebe Krisztina dr. ${ }^{9}$ - Csiszér Eszter dr. ${ }^{5,10}$ \\ Mihály Sándor dr. ${ }^{11}$ - Kovács Lajos dr. ${ }^{6}$ - Müller Veronika dr. ${ }^{5}$ \\ Elek Jenő dr. ${ }^{2}$ - Rényi-Vámos Ferenc dr. ${ }^{1,3}$ - Lang György dr. ${ }^{3,8}$ \\ Országos Onkológiai Intézet, ${ }^{1}$ Mellkassebészeti Osztály, \\ ${ }^{2}$ Aneszteziológiai és Központi Intenzív Terápiás Osztály, Budapest \\ Semmelweis Egyetem, Általános Orvostudományi Kar, ${ }^{3}$ Mellkassebészeti Klinika, \\ ${ }^{4}$ Városmajori Szív- és Érgyógyászati Klinika, ${ }^{5}$ Pulmonológiai Klinika, \\ ${ }^{6}$ I. Gyermekgyógyászati Klinika, ${ }^{7}$ Transzplantációs és Sebészeti Klinika, Budapest \\ ${ }^{8}$ Klinische Abteilung für Thoraxchirurgie, Universitätsklinik für Chirurgie, Medizinische Universität, Wien \\ ${ }^{9}$ Deák Jenő Kórház, Légzésrehabilitációs Osztály, Tapolca \\ ${ }^{10}$ Országos Korányi és Pulmonológiai Intézet, Budapest \\ ${ }^{11}$ Országos Vérellátó Szolgálat, Transzplantációs Igazgatóság, Budapest
}

\begin{abstract}
Magyarországon az első tüdőtranszplantációt 2015. 12. 12-én végeztük el az Országos Onkológiai Intézet és a Semmelweis Egyetem együttmúködésével. Cikkünkben az elmúlt két és fél év eredményeit összegezzük. 2018 augusztusáig 55 tüdőtranszplantációra került sor. Az adatfeldolgozást retrospektív módszerrel végeztük. A várólistára helyezés a Tüdő Transzplantációs Bizottság javaslatára történt. A donortüdők agyhalott donorokból származtak. A posztoperatív gondozás a Semmelweis Egyetemen folytatódott. 2015. 12. 12. és 2018. 07. 31. között 76 szervkivételen vettünk részt: 45 magyar, 23 Eurotransplant-, 8 Eurotransplanton kívüli országban, ezekből 54 kétoldali és 1 egyoldali tüdőtranszplantáció valósult meg. A mútéteket egyoldali $(\mathrm{n}=1)$, kétoldali thoracotomiából $(\mathrm{n}=1)$ vagy 'clamshell' betolásból $(\mathrm{n}=53)$, venoarterialis extrakorporális membránoxigenizáció-támogatással végeztük. Három esetben az extrakorporális membránoxigenizáció-támogatást a posztoperatív szakban prolongáltuk, másik két betegnél extrakorporális membránoxigenizáció-bridge terápiát követően végeztük el a transzplantációt. Egy kombinált tüdő-vese transzplantáció is történt. A recipiensek alapbetegsége krónikus obstruktív tüdőbetegség $(\mathrm{n}=28)$; fibrotizáló tüdőbetegség $(n=8)$; cystás fibrosis $(n=12)$; elsődleges pulmonalis hypertonia $(n=2)$; histiocytosis-X $(n=1)$; bronchiectasia $(\mathrm{n}=2)$; lymphangioleiomyomatosis $(\mathrm{n}=1)$ és bronchiolitis obliterans szindróma miatti retranszplantáció $(\mathrm{n}=1)$ volt. Átlagéletkoruk 47,5 $\pm 15,18$ év volt. A legfiatalabb beteg 13 éves volt. A várólistán 12 beteg hunyt el. A betegek átlagosan 24,6 $\pm 18,18$ napot töltöttek az intenzív osztályon. A korai posztoperatív időszakban 2 beteget vesztettünk el. Tartós lélegeztetési igény miatt tracheostomát 13 esetben készítettünk. A betegek 1 éves túlélése 82,96\% volt. A hazai tüdőtranszplantációs programban gyorsan emelkednek az esetszámok, ami más centrumok indulásához képest kivételes eredmény. A szövődmények és halálozások aránya más, nagy esetszámú centrumok számainak megfelel. A jövőben a várólista bővítését, az esetszámok további növelését, és az 'ex vivo lung perfusion' (EVLP-) rendszer használatának bevezetését szeretnénk megvalósítani.

Orv Hetil. 2018; 159(46): 1859-1868.
\end{abstract}

Kulcsszavak: tüdőtranszplantáció, magyar tüdőtranszplantációs program 


\section{The start of the Hungarian lung transplantation program and the first results}

The first lung transplantation in Hungary was performed on 12th of December, 2015. It was a joint effort of the National Institute of Oncology and the Semmelweis University. Hereby we summarise the results and experiences from the first three years. Until August, 2018, 55 lung transplantations were performed in Hungary. This was a retrospective analysis. All patients were listed according to the recommendation of the Lung Transplantation Committee. All implanted lungs have been procured from brain dead donors. Postoperative treatment and rehabilitation of the patients were continued at the Semmelweis University. Between 12. 12. 2015 and 31. 07. 2018, our team performed 76 organ retrievals: out of 45 Hungarian offers, 23 came from Eurotransplant countries and 8 outside of the Eurotransplant region. From these donations, 54 double and 1 single side transplantations were successfully performed. The surgical approach was single side thoracotomy $(\mathrm{n}=1)$, bilateral thoracotomy $(\mathrm{n}=\mathrm{l})$ and in the majority of the cases clamshell incision $(n=53)$. For the intraoperative veno-arterial extracorporeal membrane oxygenation support was used. The extracorporeal membrane oxygenation support had to be prolonged in 3 patients into the early postoperative period, two other recipients were bridged to transplant with extracorporeal membrane oxygenation. In the same time period, one combined lung-kidney transplantation was also performed. The distribution of recipients according to the underlying disease was: chronic obstructive pulmonary disease $(\mathrm{n}=28)$; idiopathic pulmonary fibrosis $(n=8)$; cystic fibrosis $(n=12)$; primary pulmonary hypertension $(n=2)$; hystiocytosis-X $(n=1)$; bronchiectasis $(\mathrm{n}=2)$; lymphangioleiomyomatosis $(\mathrm{n}=1)$; and re-transplantation following bronchiolitis obliterans syndrome $(\mathrm{n}=1)$, respectively. The mean age of recipients was $47.5 \pm 15.18$ years. The youngest recipient was 13 years old. We unfortunately lost 12 patients on our waiting list. The mean intensive care unit stay was $24.6 \pm 18.18$ days. Two patients were lost in the early postoperative phase. Tracheostomy was necessary in 13 cases due to the need of prolonged ventilation. 1-year survival of the recipients was $82.96 \%$ (until 31. 07.2018). When looking at the first three years of the program, the case numbers elevated quickly throughout the years which is rather unique when compared to other centres in their starting period. Perioperative mortality and morbidity is comparable with highvolume lung transplantation centres. In the future we would like to increase the number of patients on the waiting list, thus increasing the total number of transplantations performed, and we are also planning to implement the use of the ex vivo lung perfusion system (EVLP) in our program.

Keywords: lung transplantation, Hungarian lung transplantation program

Gieszer B, Radeczky P, Ghimessy Á, Farkas A, Csende K, Bogyó L, Fazekas L, Kovács N, Madurka I, Kocsis Á, Agócs L, Török K, Bartók T, Dancs T, Schönauer N, Tóth K, Szabó J, Eszes N, Bohács A, Czebe K, Csiszér E, Mihály S, Kovács L, Müller V, Elek J, Rényi-Vámos F, Lang Gy. [The start of the Hungarian lung transplantation program and the first results]. Orv Hetil. 2018; 159(46): 1859-1868.

(Beérkezett: 2018. szeptember 9.; elfogadva: 2018. október 3.)

\section{Rövidítések}

ACT $=($ activated clotting time $)$ aktivált alvadási idő; AITO = (Anesthesiology and Intensive Care Unit) Aneszteziológiai és Intenzív Terápiás Osztály; ATG = antithymocytaglobulin; BLTx $=$ (bilateral lung transplantation) kétoldali tüdőtranszplantáció; BOS $=$ (bronchiolitis obliterans syndrome $)$ bronchiolitis obliterans szindróma; $\mathrm{CF}=$ (cystic fibrosis) cystás fibrosis; CIT $=($ cold ischemic time $)$ hidegischaemiás idő; COPD = (chronic obstructive pulmonary disease) krónikus obstruktív tüdőbetegség; DBD = (donor after brain death) agyhalott donor; DSA $=($ donor-specific antibodies $)$ donorspecifikus antitest; $\mathrm{ECMO}=($ extracorporeal membrane oxygenation $)$ extrakorporális membránoxigenizáció; ET = Eurotransplant; EVLP $=($ ex vivo lung perfusion $)$ extrakorporális tüdőperfúzió; HLA = humán leukocytaantigén; IPF = (idiopathic lung fibrosis) idiopathiás tüdőfibrosis; ISHLT $=($ International Society for Heart and Lung Transplantation) Nemzetközi Szív- és Tüdőtranszplantációs Társaság; LAM = lymphangioleiomyomatosis; LAS $=$ Lung Allocation Score $;$ LuTx = (lung transplantation) tüdőtranszplantáció; OOI = (National Institute of Oncology) Országos Onkológiai Intézet; OVSZ SZKI = (Hungarian National Blood Transfusion Service, Organ Coordination Office)
Országos Vérellátó Szolgálat, Szervkoordinációs Iroda; PGD = (primary graft dysfunction) korai graftelégtelenség; $\mathrm{PPH}=$ (primary pulmonary hypertension) primer pulmonalis hypertonia; PRA = (panel-reactive antibody) panelreaktív antitest; PRES $=($ posterior reversible encephalopathy syndrome $)$ posterior reverzibilis encephalopathia szindróma; SLTx $=$ (single lung transplantation) egyoldali tüdőtranszplantáció; TTB = Tüdő Transzplantációs Bizottság, Tx $=$ (transplantation) transzplantáció; VA = (veno-arterial) venoarteriosus; VAC = (vacuum assisted closure) vákuumasszisztált sebkezelés; $\mathrm{VV}=$ venovenosus; $\mathrm{VVT}=($ red blood cell concentrates $)$ vörösvértest-koncentrátum

Az első tüdőtranszplantációt 1963-ban végezte James Hardy, a beteg azonban immunszuppresszív szerek hiányában csak 18 napig élt [1]. Az első tartósan sikeres egyoldali tüdőtranszplantációt Joel Cooper végezte Torontóban 1983-ban, majd 1986-ban szintén ő hajtotta végre az első kétoldali tüdőtranszplantációt is [1, 2].

$\mathrm{Az}$ International Society for Heart and Lung Transplantation (ISHLT) legutóbb közzétett statisztikája sze- 
rint 2017-ben a világon több mint 3800 tüdőtranszplantációt végeztek [3].

A Bécsi Orvostudományi Egyetem Sebészeti Klinikájának Mellkassebészeti Osztálya (Medizinische Universität Wien, Chirurgische Universitätsklinik, Abteilung für Thoraxchirurgie) jelenleg a világ egyik vezető tüdőtranszplantációs centruma, ahol 1989. 11. 08-án történt meg az első tüdőátültetés [4]. Itt végezték 1996-ban az első magyar beteg tüdőtranszplantációját, és a magyar program indulásáig további 187 magyar beteg tüdőátültetését is. A bécsi centrum hosszú éveken keresztül támogatta a tüdőtranszplantációval foglalkozó hazai szakemberek képzését. A transzplantációs folyamat egyes elemei fokozatosan kerültek bevezetésre:

1996: Az első magyar beteg tüdőtranszplantációja 1996. március 5-én, Bécsben történt meg.

2001: A transzplantált betegek gondozását 2001 januárjától centralizáltan az Országos Korányi és Pulmonológiai Intézet, a kelet-magyarországi betegek esetében pedig a Debreceni Egyetem Pulmonológiai Klinikája tartotta kézben. 2008 októberétől valamennyi új beteg posztoperatív ellátását, majd 2010-től az összes transzplantált beteg kontrollját a Semmelweis Egyetem Pulmonológiai Klinikája, illetve gyermekek esetében az I. Gyermekgyógyászati Klinika vette át.

2002: A magyarországi tüdőkivételek 2002-ben kezdődtek el az akkor létrehozott, transzplantációs centrumoktól független donorkoordinátor szervezet (Hungarotransplant Kht.) koordinációjával. 2007 óta a szervriadókat országos szinten az Országos Vérellátó Szolgálat Szervkoordinációs Irodája (OVSZ SZKI) szervezi. A hazai tüdőtranszplantációs program indulását megelőzően, kétoldalú együttmúködési megállapodás keretében, az itthon kiemelt donortüdőket lehetőség szerint magyar recipiensekbe ültették be Bécsben.

2004: Megalakult a Tüdő Transzplantációs Bizottság (TTB), amely havonta/kéthetente (de szükség esetén soron kívül is) véleményezi és vizsgálja az ország területéről érkező, tüdőtranszplantációra javasolt betegeket. A betegek a TTB javaslata alapján kerülnek a magyar és 2013-tól egyben az Eurotransplant (ET) tüdőtranszplantációs várólistára.

2012: Magyarország 2012. január 1-től előzetes együttmúködési megállapodás keretein belül, majd 2013. július 1-től teljes jogú Eurotransplant-tag lett, aminek köszönhetően a program indulásakor már külföldről is hozhattunk haza tüdőket.

2015: Az első tüdőbeültetést 2015. 12. 12-én végeztük el az Országos Onkológiai Intézetben (OOI), az Országos Onkológiai Intézet és a Semmelweis Egyetem együttmúködésében. Az első hazai tüdőátültetést a közvetlen perioperatív tevékenységben részt vevő szakemberek (sebészek, aneszteziológusok, koordinátorok, mütőasszisztensek és gyógytornászok) intenzív felkészítése előzte meg. Magyarország kormánya által nyújtott közel 1 milliárd forintos céltámogatás fedezte a szervtransz- plantáció speciális igényeit kielégítő infrastrukturális beruházásokat.

A Bécsi Tüdőtranszplantációs Centrummal továbbra is megmaradt a kapcsolat, és ez hazánk ET-szerződésének is nevesített része. Ennek értelmében bizonyos magas rizikójú betegségcsoportba tartozó recipiensek (például kis súlyú gyermek, kombinált szervtranszplantáció) elsődlegesen továbbra is Bécsben kerülnek ellátásra. Miután a hazai program infrastruktúrája és mútéti teamje jelenleg még korlátozott kapacitású, a bécsi transzplantáció lehetősége továbbra is nyitott minden magyar beteg számára, amennyiben ezt a hazai ellátási lehetőség korlátai szükségessé teszik.

\section{Anyag és módszer}

\section{Indikáció felállitása, a beteg kivizsgálása, felkészitése és listára helyezése}

Amennyiben a gondozó pulmonológus úgy ítéli meg, hogy a beteg esetében tüdőátültetés merül fel, úgy néhány alapvizsgálat elvégzését követően (labor, légzésfunkció, vérgázvizsgálat, mellkas-CT) a TTB ülésén a beteg bemutatásra kerül. A referálás az erre a célra létrehozott internetes felületen lehetséges. A bizottsági ülések helyszíne a Semmelweis Egyetem Pulmonológiai Klinikája.

A betegek szelekciója, kivizsgálása és végül a listára helyezése a szakmai bizottság javaslatára és ellenőrzése alatt, egységes irányelvek szerint zajlik.

\section{Allokáció, transzplantációs riadó megszervezése, donorszerv kiemelése és szállitása}

A szervriadókat országos szinten az OVSZ SZKI szervezi a tüdőtranszplantációs centrum koordinátoraival együttmúködve.

A listára került betegeknek az elvégzett vizsgálatok eredményei, a betegség súlyossága alapján az ET internetes felületén kiszámoljuk a Lung Allocation Score (LAS) értékét. A LAS olyan numerikus pontrendszer, mely a donorszervek allokációját hivatott segíteni. Minél nagyobb ez az érték, annál sürgősebb a tüdőátültetés. A LAS maximumértéke 100 lehet. A gyermekek (12 év alatt) automatikusan 100 pontot kapnak, mivel kis testméretük miatt csak nehezen jutnak új tüdőhöz.

Az allokáció az Eurotransplant tagországain belül, Németországban és Hollandiában a LAS alapján történik. Más országokban a centrum azonban saját maga döntheti el, hogy kit transzplantál, a bécsi centrummal együtt mi is ezt a gyakorlatot követjük. Saját donorterületről érkezett szervfelajánlás esetén a tüdőallokáció AB0-vércsoport-kompatibilitás és méretegyezés (sizematch) figyelembevételével, interdiszciplináris, egyedi szakmai döntés alapján történik (centrumallokáció). Az érvényes ET-szerződések szerint jelenleg Ausztria, Szlovénia, Horvátország és Magyarország területe számunk- 
ra lokális donor 'pool'-nak számít. Miután az ET-térben tüdő esetében 50 feletti, úgynevezett „high-LAS”-érték esetén nemzetközi allokáció is lehetséges, a LAS-értéket minden esetben kiszámoljuk, ezzel is javítva a súlyosabb állapotú, sürgős transzplantációt igénylő betegek esélyeit. Ezért az ET egyéb tagországaiból elsősorban magas LAS alapján vagy úgynevezett „rescue” allokáció során kapunk szerveket.

A veseátültetéstől eltérően a tüdőátültetés során nem törekszünk a HLA-kompatibilitásra. A mütét előtt keresztpróba-vizsgálatra logisztikai okok miatt rutinszerüen nincs lehetőség. Ha a mütét után megküldött keresztpróba pozitív, akkor emelt immunszuppressziót, szükség esetén plazmaferézist alkalmazunk. Retranszplantáció, magas HLA-ellenes antitesttiter esetén törekszünk az előzetes keresztpróba elvégzésére, ez azonban általában csak hazai donáció esetén szervezhető meg.

Magyarországi, de főleg külföldi szervkivételek esetén a szervezés során az egyik legfontosabb szempont a hidegischaemiás idő (cold ischemic time - CIT), mely ideális esetben nem haladja meg a 6-8 órát. CIT-en tüdőátültetés esetében a donoraorta lefogása és a - bilaterális transzplantáció esetén másodikként - beültetett tüdő reperfúziója között eltelt időt értjük, eközben ugyanis nincs keringése a tüdőnek, és nincs lélegeztetve.

Magyarországon jelenleg csak agyhalott (donor after brain death - DBD) donorból végzünk szervkivételt.

A szervkivétel során az arteria pulmonalis törzsön keresztül $4{ }^{\circ} \mathrm{C}$-os, alacsony káliumtartalmú, hütött dextránoldattal (Perfadex ${ }^{\circledR}$, Vitrolife, Göteborg, Svédország) perfundálva konzerváljuk a tüdőt. A hideg okozta vasoconstrictio ellensúlyozása érdekében közvetlenül az aortalefogás és a perfúzió indítása előtt potens vasodilatatort alkalmazunk (epoprosztenol). A két tüdőfelet egyben, közepesen felfújt állapotban, a bal pitvar hátsó falával együtt távolítjuk el. A két tüdőfelet csak akkor választjuk szét szállítás előtt, ha a tüdők alkalmasak beültetésre. Úgynevezett marginális (határeseti) tüdők esetében, a végső funkcionális megítéléshez a kiemelést követően ex vivo perfúziót (ex vivo lung perfusion - EVLP) alkalmazunk. Az EVLP használata során a közös kétoldali tüdőblokkon a bal pitvar visszahagyott hátsó falára és az arteria pulmonalis fötörzsre szájaztatjuk a kanülöket, valamint a tracheán keresztül lélegeztetjük a tüdőt. A módszer segítségével rekondicionálhatók, jobban megítélhetók és bizonyos esetekben biztonságosan beültetésre alkalmassá tehetők a marginális tüdők. Ha EVLP mellett döntünk, a tüdőket Bécsbe szállítjuk, mert jelenleg ez az eljárás csak a fennálló együttmúködésünk keretében férhető hozzá számunkra.

\section{Szervátültetés}

Gyakorlatunkban izolált egyoldali tüdőtranszplantáció (single lung transplantation - SLTx) során ellenoldali lélegeztetés mellett, az operált oldali tüdő eltávolítását követően kerül beültetésre az új tüdő. A kétoldali tüdőátül- tetés ugyanennek a technikának a szekvenciális formája, azaz két izolált („egymás után két egyoldali”) tüdőtranszplantáció (bilateral lung transplantation - BLTx). A mütéteket egy- vagy kétoldali anterolateralis thoracotomiából vagy 'clamshell' metszésből végezzük (ez utóbbi két, általában a negyedik bordaközben végzett anterolateralis thoracotomia haránt sternotomiával öszszekötve).

A tüdőfelek beültetésekor a három fő képlet - sorrendben a hörgő, a bal pitvar, majd az arteria pulmonalis - vég a véghez anasztomózisát tovafutó varratsorral készítjük. A főhörgő-anasztomózist 4-0 PDS tovafutó, a bal pitvari anasztomózist 4-0 Prolene tovafutó, az arteria pulmonalis végeket 5-0 Prolene tovafutó varrattal egyeztetjük.

Donor/recipiens méretdiszkrepancia esetén a nagyobb tüdő mintegy 20\%-os megkisebbítését a leggyakrabban a középlebeny és/vagy a lingula atípusos gépi tüdőállomány reszekciójával érjük el. Jelentősebb 'sizemismatch' esetén lebenyátültetést (lobar-TX) végzünk. Ilyenkor az implantáció előtt extracorporalis lobectomiát követően végezzük a mérete, illetve alakja szerint kiválasztott lebenyek oldalazonos beültetését.

A transzplantációkat saját gyakorlatunkban venoarteriosus (VA) ECMO (Cardiohelp System, Maquet GmbH, Rastatt, Németország) támogatással operáljuk. A vénás kanült a jobb pitvarba, az artériás kanült az aorta ascendensbe helyezzük be. A kanüláláshoz heparinbevonatos (vénás: CB96825; CB6570; CB667; CB67636; CB91437C; artériás: CB77618; CB77620; Medtronic Kft., Budapest) kanülöket alkalmazunk. A kanüláláshoz csak részleges antikoagulálás szükséges, melyet iv. adott heparinnal (60-70 NE/ttkg) végzünk. Az aktivált alvadási idő (activated clotting time - ACT) célértéke gyakorlatunkban 180 és 220 s közötti. Súlyos primer graftelégtelenség (primary graft dysfunction - PGD) esetén, illetve PPH-s recipiensek esetén a VA ECMO-támogatást a posztoperatív szakban is folytatjuk.

Bridge-to-TX indikációval alkalmazott ECMO-terápia esetén a venovenosus (VV) ECMO-eljárásokat preferáljuk, a kanülálást Seldinger-technikával végezzük jugularis, illetve inguinalis behatolásból (femorojugularis VV ECMO).

A korai graftdiszfunkció (PGD) nemzetközi adatok szerint a tüdőtranszplantációk 10-25\%-át érinti, és a korai poszttranszplantációs morbiditás és mortalitás fó oka

1. táblázat | A PGD-fokozatok klasszifikációja

\begin{tabular}{lll}
\hline Fokozat & $\mathrm{PaO}_{2} / \mathrm{FiO}_{2}$ & A tüdőödéma radiológiai jelei \\
\hline 0. & $>300$ & Nem észlelhető \\
1. & $>300$ & Észlelhető \\
2. & $200-300$ & Észlelhető \\
3. & $<200$ & Észlelhető \\
\hline
\end{tabular}

$\mathrm{PaO}_{2}=$ parciális oxigénnyomás; $\mathrm{PGD}=$ korai graftelégtelenség; $\mathrm{FiO}_{2}$ = a belélegzett oxigén aránya 
[5, 6]. A PGD mértékét az érvényes ISHLT-klasszifikáció alapján értékeljük (1. táblázat).

Egyes esetekben például előrehaladott PPH-s betegeknél, szupraszisztémás pulmonalis tensiónál az intubációt követően indított, pozitív nyomású lélegeztetés okozta mellkasi nyomásemelkedés hemodinamikai öszszeomlást okozhat. Ezekben az esetekben lokális érzéstelenítésben, már altatás előtt perifériás behatolásból vezetjük be a (VA) ECMO-t, vagy JET-lélegeztetést (Monsoon JET, Acutronic Medical Systems, Hirzel, Svájc) alkalmazunk a centrális ECMO elindításáig.

\section{Korai posztoperativ idöszak, intenzines gondozás}

A betegek gondozása a korai időszakban az AITO külön transzplantációs célra elkülönített részlegén, a transzplantációs őrzőben történik. Az elsődleges cél a betegek keringési, légzési, hasi és pszichés statusának rendezése, a lélegeztetőgéprôl való leszoktatása, az immunszupreszszív szerek beállítása, a beteg mobilizálása. Korán elkezdjük az ágyban használható, fekvő kerékpározás passzív és aktív formáját. A kerékpározás stimulálja a bélmozgásokat, növeli az izomerőt és a cardiopulmonalis terhelhetóséget.

Az immunszuppresszió részeként betegeink indukciós terápiát kapnak, amennyiben ennek speciális kontraindikációja nincs. Ezt követően kettős, késôbb hármas kombinációjú bázisterápiát állítunk be

1. Indukciós kezelés: alemtuzumab (Campath) 0,4$0,5 \mathrm{mg} / \mathrm{ttkg}$ vagy polyclonalis antithymocytaglobulin (ATG) $2 \mathrm{mg} / \mathrm{ttkg}$.

2. Bázisterápia:

- Kalcineurininhibitorok: saját gyakorlatunkban takrolimuszt (Prograf) $0,01 \mathrm{mg} / \mathrm{ttkg} / 24$ ó alkalmazunk rutinszerúen. A kívánt vérszint: $8-10 \mathrm{ng} / \mathrm{ml}$.

- Purinszintézis-gátlók: rutinszerúen mikofenolátmofetilt (CellCept) alkalmazunk. Ha a transzplantációt követően Campathtal történt indukciós kezelés, akkor l évvel a mútétet követően vezetjük be 1-2 $\times 500 \mathrm{mg} /$ napi dózisban adva. Ha ATG-vel történt az indukció, akkor a Tx-t követően rögtön adjuk, $3 \times 1$ g-ot naponta.

- Szteroid: prednizolont vagy metilprednizolont alkalmazunk. Fél-egy órával a donortüdő reperfúziója előtt 500-1000 mg metilprednizolont adunk. A reperfúziót követő 8., 16., és 24 . órában $125 \mathrm{mg}$, majd 24 óra után $1 \mathrm{mg} / \mathrm{ttkg}$ napi dózist alkalmazunk, amelyet fokozatosan csökkentünk.

A per os immunszuppressziót csak akkor indítjuk, amikor már rendeződött a betegek emésztése, megindult a bélmúködésük.

\section{Utógondozás/rehabilitáció}

A betegek optimális esetben kb. 2-4 hetet töltenek intézetünkben. Rehabilitáció és utógondozás céljából pulmonológiai osztályra kerülnek áthelyezésre, ahol orvosi ellenőrzés mellett rendszeres, gyógytornász felügyeletével végzett edzést, izomépítést, valamint gyógyszerbeállítást, az otthoni, mindennapi életre való felkészülést végeznek. Itt történik a javasolt gyógyszerek beszerzése, szükség esetén engedélyeztetése és a segédeszközökkel való ellátás. A mútét utáni, kórházi rehabilitációval eltöltött idő általában 3-4 hét. A betegek állapotát a funkcionális paraméterek mérésével, bronchoszkópos szövettani mintavétellel, illetve CT-vizsgálattal ellenórizzük. A transzplantáltak hazabocsátásukat követően meghatározott időrendben rendszeresen kontrollra jelentkeznek tüdőgyógyász teamnél.

A hazai gondozás centruma a Semmelweis Egyetem: a felnőtt transzplantáltakat a Pulmonológiai Klinika, a gyermekeket az I. Gyermekgyógyászati Klinika gondozza.

\section{Eredmények}

\section{Várólistaadatok}

2017. december 31-én a tüdőtranszplantációs várólistán 12 aktív beteg volt, ez a szám lassan, de folyamatosan növekedett a vizsgált időszakban (1. ábra). A transzplantált betegek várólistán eltöltött medián ideje 50 (range 1-427) nap volt. A tüdőtranszplantációs várólistán öszszesen 12 beteg halt meg a program indulása és 2018. 07. 31. között, a várólista mortalitása 15\%-os. A listán eltöltött medián idő az elhunytak esetében 106 (range 4-481) nap volt.

\section{Tüdő Transzplantációs Bizottság}

A megjelenő betegek száma 2013-tól folyamatosan emelkedik, az utolsó évben összesen 85 beteg került bemutatásra az üléseken. A beutaló diagnózisok megoszlásának aránya közel állandó (2. ábra).

\section{Szervkivételek}

2015. 12. 12. és 2018. 07. 31. között összesen 76 szervkivételen vettünk részt: 45 magyar, 23 Eurotransplant-, 8 Eurotransplanton kívüli országban. A LAS alapján

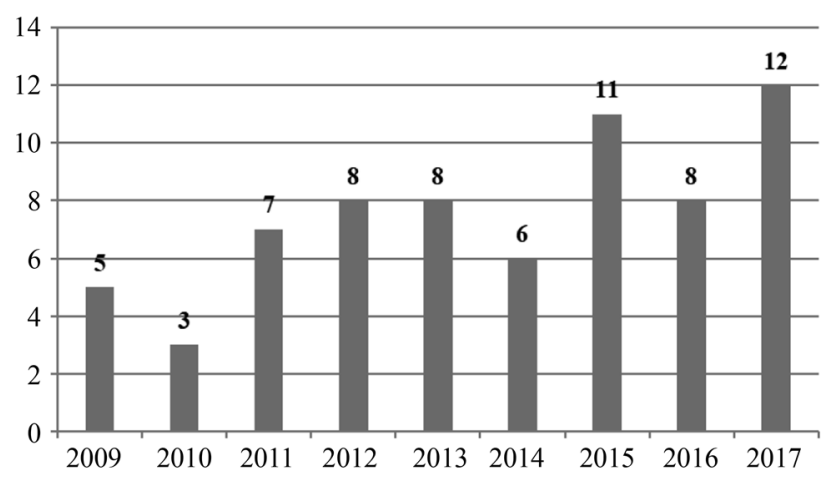

1. ábra | Várólistán lévő betegek száma az adott év december 31-én 


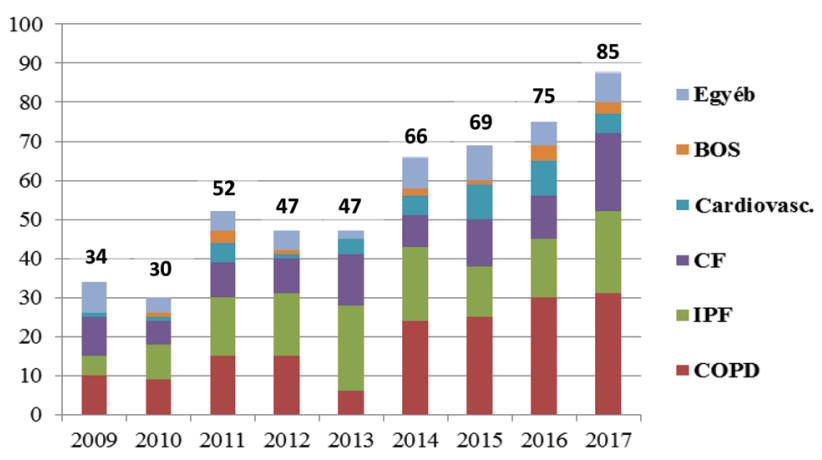

2. ábra

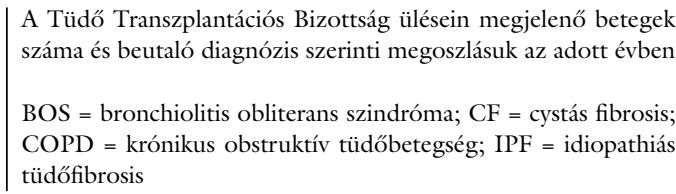

meghatározott direkt allokáció 4 esetben volt, a többi 72 esetben centrumallokáció szerint történt a recipiens kiválasztása. 21 esetben sajnos nem volt alkalmas beültetésre a donortüdő, így a transzplantáció meghiúsult. A recipiens magas anti-HLA-titere és retranszplantáció miatt 3 alkalommal volt szükség preoperatív 'crossmatch' vizsgálatra.

\section{Betegek}

$\mathrm{Az}$ első magyar beteg bécsi tüdőtranszplantációja óta 2018 augusztusáig összesen 187 bécsi és 55 budapesti tüdő́tültetés történt magyar betegbe (3. ábra).

A Bécsben, illetve a Budapesten transzplantált betegek diagnózisának megoszlását a 2. táblázat tartalmazza. A legtöbb transzplantációt krónikus obstruktív tüdőbetegség (COPD) miatt végeztük.

Budapesten 2017-ben volt az első primer pulmonalis hypertoniás (PPH-) beteg hazai szervátültetése és az
2. táblázat A magyar betegek tüdőtranszplantációs diagnózisának megoszlása (2015. december-2018. július)

\begin{tabular}{lcc}
\hline Alapbetegség & LuTx Bécs $(\mathrm{n}=9)$ & LuTx Budapest $(\mathrm{n}=55)$ \\
\hline Felnött & 0 & 28 \\
\hline COPD & 1 & 7 \\
IPF & 0 & 1 \\
IPF/ECMO-bridge & 0 & 9 \\
CF & 0 & 1 \\
CF/Tüdő-vese Tx & 1 & 0 \\
CF/Tüdö-máj Tx & 0 & 1 \\
CF/ECMO-bridge & 2 & 2 \\
PPH & 1 & 0 \\
PPH/ECMO-bridge & 0 & 1 \\
Histiocytosis & 0 & 2 \\
Bronchiectasia & 1 & 0 \\
Sarcoidosis & 0 & 1 \\
LAM & 0 & 1 \\
BOS (re-Tx) & & 1 \\
\hline Gyermek & 1 & 0 \\
\hline CF & 1 & 0 \\
CF/ECMO-bridge & 1 & \\
PPH/ECMO-bridge & & \\
\hline & &
\end{tabular}

$\mathrm{BOS}=$ bronchiolitis obliterans szindróma; $\mathrm{CF}=$ cystás fibrosis; $\mathrm{COPD}$ = krónikus obstruktív tüdőbetegség; ECMO = extrakorporális membránoxigenizáció; $\mathrm{IPF}=$ idiopathiás tüdőfibrosis; $\mathrm{LAM}=$ lymphangioleiomyomatosis; $\mathrm{LuTx}=$ tüdőtranszplantáció; $\mathrm{PPH}=$ primer pulmonalis hypertonia; $\mathrm{Tx}=$ transzplantáció

első kombinált (tüdő-vese) transzplantáció is, a Transzplantációs és Sebészeti Klinikával együttmúködve. 2018ban elvégeztük az első gyermek- és az első retranszplantációt. Két alkalommal ECMO-bridge terápiát követően végeztük el a mütétet.

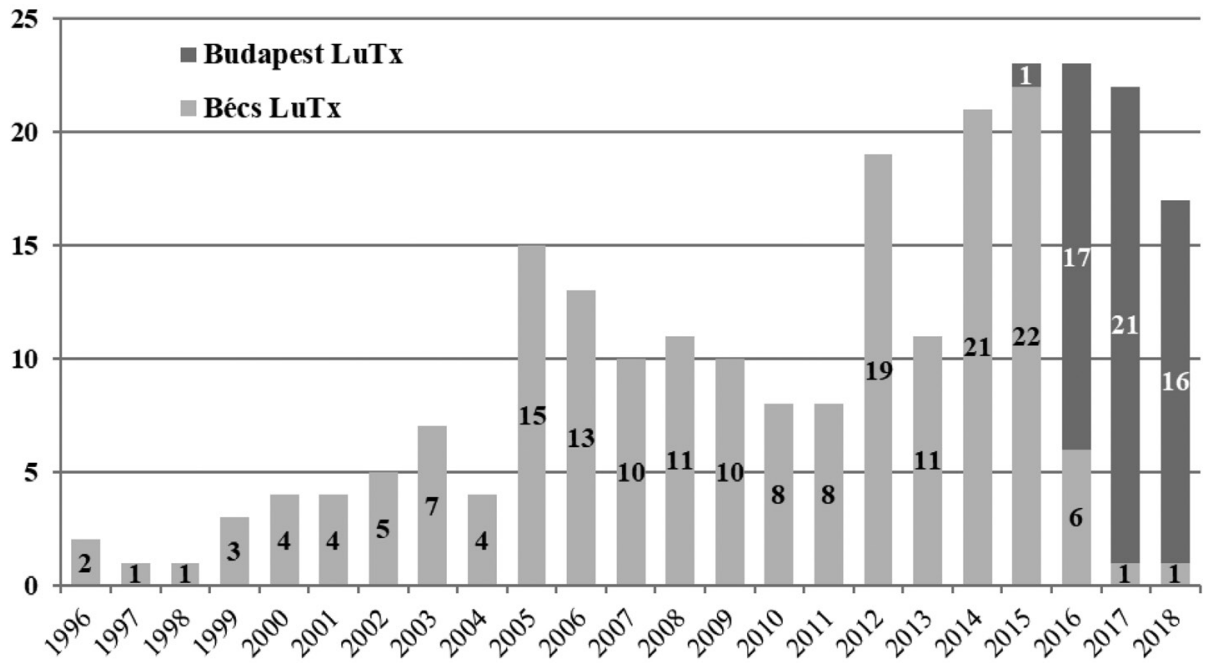

\begin{tabular}{l|l} 
3. ábra & $\begin{array}{l}\text { Magyar betegek tüdőtranszplantációi Bécsben és Budapesten } \\
\text { LuTx }=\text { tüdőtranszplantáció }\end{array}$
\end{tabular} 
A LAS értéke átlagosan 37,46 $\pm 11,81$ volt a transzplantáció időpontjában. A betegek átlagéletkora a transzplantáció időpontjában 47,5 $\pm 15,18$ év volt. A legfiatalabb 13 éves CF-es, a legidősebb, 65 éves COPD-s beteg volt. A nemek aránya: $53,7 \%$ férfi, $46,3 \%$ nő.

Az utólagos HLA 'crossmatch' vizsgálat egy beteg esetében lett pozitív. 3 betegnél volt szükség előzetes 'crossmatch' vizsgálatra: 1 esetben magas PRA (21\%) miatt; 2 esetben retranszplantáció miatt. Sajnos az egyik retranszplantációra váró beteg az életmentő tüdő megérkezése előtt elhunyt. A magas panelreaktív antitest (panel-reactive antibody - PRA) szinttel rendelkező betegnél közvetlenül a transzplantációs mútét előtt egy és a mütét után több alkalommal végeztünk plazmaferézist.

\section{Transzplantációs mütét}

A Budapesten elvégzett 55 tüdőtranszplantációból 54 kétoldali és 1 egyoldali átültetést végeztünk. 53 esetben 'clamshell' behatolásból, l esetben kétoldali anterolateralis thoracotomiából, 1 esetben egyoldali anterolateralis thoracotomiából végeztük a mútétet.

Magas pulmonalis nyomás miatt 5 esetben JET-lélegeztetéssel, egy esetben perifériás ECMO védelmében történt az anesztézia bevezetése.

Negyven esetben a donortüdők reszekció nélkül kerültek beültetésre, 9 esetben kétoldali, 4 esetben egyoldali atípusos reszekciót végeztünk. 2 kritikus beteg esetében nem volt idő megvárni a méretben megfelelő tüdőt, ezért a donor-recipiens méretaránytalanság miatt az egyik oldalra csak egy lebeny beültetését végeztük.

Három beteget kivéve az összes mútétet centrális venoarterialis ECMO védelmében végeztük. 1 beteg esetében egyáltalán nem alkalmaztunk, 2 betegnél perifériás behatolásból került bevezetésre ECMO. Az átlagos ECMO-idő $201,9 \pm 36,51$ perc volt. Prolongált, posztoperatív perifériás ECMO-kezelést 3 betegnél alkalmaztunk, melyet két esetben 4, egy esetben 3 napig folytattunk.

A mútétek során átlagosan $5 \pm 0,57$ egység (E) szürt, sugarazott vörösvértest-koncentrátumot (VVT) és $10 \pm$ 2,6 E Octaplas (Octapharma AG, Lachen, Svájc) készítményt használtunk fel.

Az átlag CIT-idő az elsőként beültetett tüdők esetében $322,44 \pm 41,13$ perc, a másodikként beültetett tüdők esetében $403,54 \pm 42,61$ perc volt.

\section{Posztoperativ időszak és túlélés}

Tartós lélegeztetés szükségessége miatt a betegek 23,6\%ánál tracheostomát készítettünk. A betegek áltagosan 24,6 $\pm 18,18$ napot töltöttek az intenzív osztályon. A Semmelweis Egyetem Pulmonológiai Klinikájára történó áthelyezést megelőzően 18 beteget ápoltunk Mellkassebészeti Osztályunkon, ahol az átlagosan eltöltött idő 6,8 \pm 3,19 nap volt.

A betegek Kaplan-Meier szerinti 1 éves túlélése (2018. 07. 31-ig bezárólag) 82,96\% volt (4. ábra).

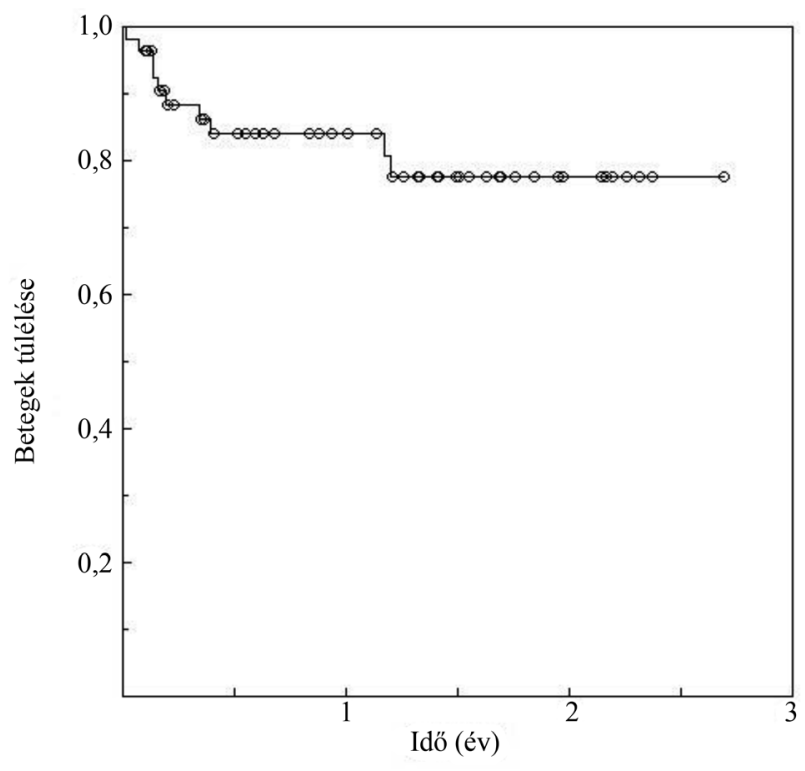

4. ábra $\quad$ A Budapesten transzplantált betegek túlélése

\section{Korai szövődmények}

Intraoperatív halálozás nem történt egy esetben sem. A korai posztoperatív időszakban, 30 napon belül 2 beteget veszítettünk el. Az egyik beteg passenger lymphocyta szindróma okozta sokk miatt, a másik beteg fulmináns szepszis miatt hunyt el a posztoperatív 26., illetve 5 . napon. További 2 beteget vesztettünk el 30 napon túl az intézetben történó ápolási időszak alatt uralhatatlan szepszisben.

A PGD incidenciája alacsony volt, súlyos formáját nem észleltük. 3 beteg esetében a PGD grade 1, egy beteg esetében grade 2 volt. Posztoperatív vérzés miatt 5 betegnek végeztünk haematomaevakuációt, két esetben korai dekortikációt. A nervus phrenicus egyoldali sérülése két esetben fordult elő, egy esetben rekeszduplikációt végeztünk. Egy betegünknél nervus hypoglossus paresis miatt a nyelv mozgása szinte teljesen kiesett, aminek okát biztosan nem tudtuk meghatározni, gyógyszertoxicitást feltételeztünk. Posterior reverzibilis encephalopathia szindróma (PRES) 5 betegnél fordult elő. Vesepótló kezelésre egy esetben sem volt szükség.

\section{Késoii szövődmények}

A 'clamshell' metszés sebének gyógyulási zavara miatt 3 alkalommal kellett VAC-kezelést alkalmaznunk, 2 esetben pedig musculus latissimus dorsi lebeny beforgatással sikerült a végleges sebgyógyulást elérni. Hörgőanasztomózis-szúkület miatt 4 esetben volt szükség bronchoszkópos intervencióra (ballonos tágítás, sztentelés). Krónikus rejekció 2 esetben fordult elö, az egyik beteget 8 hónappal az első transzplantációt követően retranszplantáltuk, a másikat sajnos 14 hónappal a Tx-mútét után elvesztettük. 


\section{Megbeszélés}

A tüdőtranszplantációs várólistán regisztrált betegek száma a vizsgált időszakban lassan, de folyamatosan növekedett. Ha azonban az Eurotransplant-adatokat vesszük alapul, akkor a magyar tüdővárólista feltöltöttsége 20,3\%-os. Ehhez viszonyítva a tüdőtranszplantációs várólistánkon mintegy 59 recipiensnek kellene folyamatosan lennie. Ez a különbség azt jelenti, hogy sok hazai beteg még nem jut el a tüdőtranszplantációig, holott az életük megmenthető lenne.

A tüdőtranszplantációs várólistán összesen 12 beteg halt meg a program indulása óta: 2016-ban 7 beteget, 2017-ben 2 beteget, 2018-ban (2018. július 31-ig) 3 beteget vesztettünk el, a várólista mortalitása 15\%-os.

A 2016-os évet kiemelve jól azonosíthatók ennek egyes meghatározó tényezői: egy elvesztett betegünk 50 napnál rövidebb ideig volt a várólistán, vagyis nagyon előrehaladott állapotban került a látóterünkbe. Egy fiatal CF-es beteg esetében Burkholderia cepacia miatt húzódott el a listázás, és többször inaktiválni kellett szeptikus problémák miatt; másik 2 beteg esetében a várólistán eltöltött idő volt hosszú (481, 193 nap), egyiküket (bridge to transplant) ECMO-ra tettük, de az életmentő tüdő érkezése előtt elvesztettük. Különösen tragikus kis súlyú, de a 12. életévét már betöltött gyermek halála. Sajnos a LAS-rendszer csak a 12 év alatti gyermekeknek biztosít prioritást a várólistán, a gyermek donorok száma pedig alacsony. 2 további elvesztett beteg alapbetegsége PPH volt: a hirtelen halál ebben a betegségben közismerten gyakori, nincs ismert várólista-mortalitást jelző prognosztikai tényező, ezért a LAS-rendszerben sem sikerült leképezni a sürgősségüket.

Bár az összesített várólista-mortalitásunk magasnak tünik, az átlagot csak kismértékben haladja meg: az ETvárólista mortalitása 2017-ben 12,4\% volt. Ugyanakkor a várólistán eltöltött medián idő az ET-ben 152 nap ( $\approx 5$ hónap), ami jóval több, mint Magyarországon, ahol a transzplantált betegeknek 50 napos ( $\approx 2$ hónapos), míg az elhunyt betegeknek 106 napos ( $\approx 3,5$ hónapos) a medián várakozási ideje. Az alacsony várakozási idő a jó donorellátottságnak és a relatíve alacsony várólista-feltöltöttségnek köszönhető. Ugyanakkor sajnos a betegek még mindig sok esetben csak későn, súlyos állapotban kerülnek a transzplantációs program látókörébe, és kicsúsznak a transzplantációs időablakból.

Az első magyar beteg bécsi tüdőtranszplantációja óta 2018 augusztusáig összesen 187 bécsi és 55 budapesti tüdőátültetés történt magyar betegbe. Ha az induló transzplantációs programunk esetszámait nézzük, akkor más transzplantáló centrumokkal összehasonlításban kiemelkedő teljesítménynek számít, hogy az első években elértük a 20 körüli esetszámot. A magyar program indulása után 8 esetben magas rizikójú betegség miatt, 2 esetben kapacitáshiány miatt történt a bécsi centrumban a beteg tüdőátültetése, ugyanakkor 2,5 évvel az indulásunk után elvégeztük már az első gyermek, és az első
PPH-s beteg szervátültetését, az első kombinált (tüdővese) és az első retranszplantációt, illetve két alkalommal ECMO-bridge terápiát követően végeztünk tüdőátültetést. Ezeket a nagy rizikójú mútéteket nemzetközi összehasonlításban is csak a legnagyobb felkészültségű centrumok tudják vállalni. Jelenleg csak a kis súlyú $(25 \mathrm{~kg}$ alatti) gyermekek, bizonyos kombinált tüdőtranszplantációk (tüdő-máj Tx, tüdő-szív Tx) és kapacitáshiány esetén történik magyar recipiens transzplantációja a bécsi centrumban. A legtöbb transzplantációt, 28 esetben COPD miatt, 12 esetben CF miatt és 8 esetben IPF miatt végeztük. A nemzetközi, ISHLT-adatok szerint is COPD miatt végzik a legtöbb tüdő́tültetést, azonban a második helyen az IPF szerepel [3].

Az 55 tüdőtranszplantációból 54 kétoldali és 1 egyoldali átültetést végeztünk. A nem infektív parenchymás tüdőbetegségek (például IPF, COPD) esetében egyoldali átültetés is végezhető, míg az infektív (például CF-) eredetû esetekben mindig bilaterális transzplantáció szükséges, és a vascularis csoportban (például PPH) is ezt preferáljuk. Ugyanis a fertőzéses csoportban meghagyott saját tüdő az immunszupprimált betegben infektív rezervoárként múködhet, a vascularis csoportban pedig az egyoldali átültetés után instabil és nehezen uralható hemodinamikai helyzet alakulhat ki. Miután a hazai programban a szervdonációs aktivitás és a kielégítő tüdődonációs potenciál nem kényszerített az egyoldali transzplantációk irányába, így a nemzetközi gyakorlatnak megfelelően, lehetőség szerint törekedtünk a kétoldali átültetésre, mivel ebben a csoportban jobbak a hoszszú távú túlélési eredmények [7,8]. Egyoldali átültetést egy esetben végeztünk, ennek a betegnek korábban talkumos pleurodesist végeztek az ellenoldali mellkasfélben.

A Budapesten elvégzett 55 tüdőtranszplantációból 2 beteg kivételével az összes mútétet 'clamshell' behatolásból végeztük. Az egyik esetben csak egyoldali tüdőátültetésre került sor a már fentebb említett ellenoldali pleurodesis miatt. A másik esetben, a beteg köpetéből kitenyészett Mycobacterium abscessus-törzs miatt, kétoldali anterolateralis thoracotomiából végeztük el a mütétet a sternum átvágása nélkül, ugyanis ezekben az esetekben rendkívül magas a sternum gyógyulási zavarainak kockázata. A korai posztoperatív szakban mért funkciós paraméterek alapján a kétoldali thoracotomia ugyan kíméletesebb a 'clamshell' behatolásnál, de sok esetben rosszabb feltárást biztosít [9]. Centrális keringéstámogatás igénye (például ECMO, szívmotor) esetén a 'clamshell' behatolás kiváló hozzáférést ad mind a kanüláláshoz, mind a tüdőhilusokhoz.

$\mathrm{Az}$ összes mútétet centrális, venoarterialis ECMO védelmében végeztük három esetet leszámítva. Az egyik beteg esetében a lap szerint kitapadt tüdő leválasztásából származó diffúz vérzés miatt tekintettünk el az ECMO és a következményes antikoagulálás alkalmazásától. A másik két esetben perifériás VA ECMO-t alkalmaztunk. $\mathrm{Az}$ egyik előrehaladott, szupraszisztémás pulmonalis 
nyomással bíró, PPH-s betegnél már altatás előtt, lokális érzéstelenítésben szükség volt az ECMO használatára. VA ECMO-t vezettünk be inguinalis behatolásból, így stabilizálva a beteg keringését, és a mútétet a perifériás támogatással végeztük el. A másik beteg esetében csak bal oldali tüdőátültetés történt, és bal oldali anterolateralis thoracotomiából végeztük a mütétet. Mivel a vénás kanül behelyezése ebből a feltárásból nem kivitelezhető, inguinalis behatolásból történt a VA ECMO bevezetése.

BLTx esetén a második oldal mútéte alatt a teljes perctérfogat az elsőként beültetett új tüdőn halad át, ami a rövidebb CIT-idő ellenére is jelentős károsító tényező, és mindig kisebb-nagyobb reperfúziós ödéma képében észlelhető. A mütét végén az elsőként beültetett tüdő nehezebb, compliance-e rosszabb, a korai mellkas-röntgenfelvételeken ez az oldal jellegzetesen fedettebb ('first lung syndrome'). A VA ECMO előnye, hogy csökkenthetjük a kis vérkör keringő vértérfogatát ('bypass'), így mérsékelhetjük az új tüdőre eső keringési volument, ugyanakkor a gázcsere is biztosítva van. A nemzetközi gyakorlatban sok centrumban szívmotoron végzik ezeket a mütéteket. Az ECMO előnye a szívmotorhoz képest, hogy csak részleges antikoagulálás szükséges, mivel zárt rendszerben történik a vér keringetése, gázcseréje, így jelentősen csökken az intraoperatív vérzés mennyisége. További pozitívum, hogy szükség esetén mútét után az extracorporalis támogatás prolongálható perifériás (általában inguinalis) behatolásból.

Magas pulmonalis nyomás esetén több esetben JETlélegeztetést alkalmaztunk a centrális ECMO elindításáig. A nyílt rendszerü JET-lélegeztetés minimális volumennel és nagy frekvenciával biztosítja a légcseréhez szükséges gázáramlást, így nem emeli jelentősen az intrathoracalis nyomást. Tapasztalataink alapján ezzel a technikával biztonsággal kivédhető a fenyegető keringésösszeomlás.

Jelenleg a bécsi centrummal közös a várólistánk és a donor 'pool'-unk is. A közös várólista egyik előnye, hogy szükség esetén a tüdőtranszplantációs mütétek Bécsben is elvégezhetók. A közös donor 'pool'-ból is centrumallokáció alapján határozhatjuk meg a recipienst, ami sok esetben lerövidíti a várólistán a várakozási időt (például gyermek, kis mellkas, immunológiai problémák esetén). A LAS bevezetése az Egyesült Államokban kezdődött; az allokációs eszköz fó célja az volt, hogy csökkentse a várólista-mortalitást, és javítsa a transzplantációt követő 1 éves túlélést, ami ott sikerült is, de ez még ma sem éri el a centrumallokáció által biztosított indikátorokat, ezért több ET-tagországgal együtt jelenleg mi is ez utóbbi allokációs rendszert preferáljuk. Az ET-tagságnak köszönhetően az ET-tagországokból is számos tüdő kerül Magyarországon beültetésre. 2015. 12. 12. és 2018. 07. 31. között összesen 76 szervkivételen vettünk részt, melyeknek kicsit kevesebb, mint a fele (31) külföldi szervkivétel volt.
Az átlag CIT-idő a másodikként beültetett tüdők esetében $403,54 \pm 42,61$ perc volt, ami az elvárt 8 órán belül van.

A nemzetközi összehasonlításban kiemelkedően alacsony PGD-incidencia valószínúleg az intraoperatív ECMO konzekvens használatával függ össze. Nem volt egy esetben sem szükség vesepótló kezelésre, ami azért kimagasló eredmény, mert a korai posztoperatív szakban a tüdőt „szárazon”, a betegek folyadékegyensúlyát negatív oldalon kell tartani. Az érzékeny egyensúly megtalálása az intenzív osztályos kezelés színvonalát minősíti.

Intraoperatív halálozás nem volt, ugyanakkor a korai időszakban 2 beteget vesztettünk el. Az egyik beteg valószínúleg passenger lymphocyta szindróma okozta uralhatatlan sokk miatt hunyt el a posztoperatív 26. napon, a másik beteg már a transzplantáció időpontjában kritikus állapotban volt, és végül befolyásolhatatlan szepszisben vesztettük el a posztoperatív 5 . napon. További 2 beteget vesztettünk el 30 napon túl az intézetben történő ápolási időszak alatt szepszisben.

A betegeket általában közvetlenül az AITO-ról helyeztük át Pulmonológiai Osztályra, és csak 18 beteg esetében volt köztes, Mellkassebészeti Osztályon történő ápolás. Ezekben az esetekben a betegek már nem igényeltek intenzív osztályos ellátást, de sebészeti (mellkasi szívódrén, sebgyógyulási zavar stb.) vagy egyéb okból nem voltak még átadhatók.

A betegek 1 éves túlélése 82,96\%-volt, ami az ISHLT adataival összehasonlítva jobb, mint a nemzetközi 78\%-os átlag [3].

A tüdőtranszplantációs programunk egyik erőssége, hogy olyan centrumban kapott helyet, ahol évente több mint ezer mellkassebészeti nagymútétet végzünk, ennek megfelelően az intenzív osztálynak kiemelkedő rutinja van az általános mellkassebészeti posztoperatív betegellátásban, beleértve a szövődmények kezelését is. A program indításakor további előny volt, hogy a transzplantációs folyamatnak több eleme is - donorprogram, kivizsgálás és elókészítés, utógondozás - már bejáratottan múködött Magyarországon [10,11].

Szeretnénk a transzplantációk számát ugyanakkor tovább növelni. Nemzetközi adatok alapján (9,8 milliós magyar népességgel számolva) évente 30-40 tüdőtranszplantáció lenne szükséges hazánkban. Az elvégezhető transzplantációk számát a világon szinte mindenhol a rendelkezésre álló donorszervek határozzák meg. Magyarországon az elmúlt években körülbelül 30-40 tüdődonáció valósult meg. Itthon a beültetések számát jelenleg a várólistán lévő betegek száma korlátozza a leginkább, ami szakmailag tarthatatlan. Sajnos nehézséget jelent a recipiensek transzplantáció előtti kivizsgálása. Ez komplex folyamat, a rutin-betegellátás mellett nagy terhet ró a kivizsgálóintézmények személyzetére, és jelenleg súlyosan alulfinanszírozott. Megoldást csak a kivizsgálás jobb finanszírozása és centralizálása jelentene. $\mathrm{Az}$ erre vonatkozó javaslatot a Szakmai Kollégium Transzplantációs, Tüdőgyógyászati és Mellkassebészeti 
Tagozata közösen dolgozta ki és terjesztette a döntéshozók elé.

A tüdőtranszplantáció utáni első évet túlélő betegek medián túlélése 8,1 év [3]. Az új tüdővel a betegek viszszaállhatnak a munkájukba, elkezdhetnek sportolni, utazni, aktívan élni. Beszédes teljesítmény, hogy a centrumunk részvételével 2017 nyarán, egy nemzetközi expedíció keretein belül, 8 tüdőtranszplantált ( 2 magyar) megmászta a Kilimandzsáró 5895 m magas csúcsát.

A jövőben azt szeretnénk elérni, hogy a várólista feltöltöttsége megfeleljen a nemzetközi átlagnak, valamint célunk, hogy növeljük az átültetések számát, és emellett új technikákat (például EVLP) is bevezessünk. Megvalósításra vár a kombinált szív-tüdő és tüdő-máj átültetések elindítása is Magyarországon.

Anyagi támogatás: A közlemény megírása anyagi támogatásban nem részesült.

Szerzôi munkamegosztás: Az irodalomkutatásban, a kézirat összeállításában és megírásában a szerzők egyenlő mértékben tevékenykedtek. A cikk végleges változatát valamennyi szerző elolvasta és jóváhagyta.

Érdekeltségek: A szerzőknek a cikk megírásával kapcsolatban nincsenek érdekeltségeik.

\section{Köszönetnyilvánítás}

A magyar tüdőtranszplantációs program nevében ezúton is köszönjük a Bécsi Tüdőtranszplantációs Centrum segítségét és Walter Klepetko professzor úr támogatását.

\section{Hasznos linkek}

http://www.onkol.hu/hu/tudotranszplant http://semmelweis.hu/mellkassebeszet/tudotranszplantacio https://tudogyogyasz.hu/Page/Index/16919

\section{Irodalom}

[1] Toronto Lung Transplant Group. Unilateral lung transplantation for pulmonary fibrosis. N Engl J Med. 1986; 314: 11401145 .

[2] Patterson GA, Cooper JD, Dark JH, et al. Experimental and clinical double lung transplantation. J Thorac Cardiovasc Surg. 1988; 95: 70-74.

[3] Lund LH, Khush KK, Cherikh WS, et al. The Registry of the International Society for Heart and Lung Transplantation: thirty-fourth adult heart transplantation report -2017 . J Heart Lung Transplant. 2017; 36: 1037-1046.

[4] Klepetko W, Grimm M, Laufer G, et al. Uni- and bilateral lung transplantation: surgical results and experiences of the lst year. Vienna Lung Transplant Group. Wien Klin Wochenschr. 1991; 103: 728-733.

[5] Christie JD, Kotloff RM, Ahya VN, et al. The effect of primary graft dysfunction on survival after lung transplantation. Am J Respir Crit Care Med. 2005; 171: 1312-1316.

[6] Daud SA, Yusen RD, Meyers BF, et al. Impact of immediate primary lung allograft dysfunction on bronchiolitis obliterans syndrome. Am J Respir Crit Care Med. 2007; 175: 507-513.

[7] Black MC, Trivedi J, Schumer EM, et al. Double lung transplants have significantly improved survival compared with single lung transplants in high lung allocation score patients. Ann Thorac Surg. 2014; 98: 1737-1741.

[8] Force SD, Kilgo P, Neujahr DC, et al. Bilateral lung transplantation offers better long-term survival, compared with single-lung transplantation, for younger patients with idiopathic pulmonary fibrosis. Ann Thorac Surg. 2011; 91: 244-249.

[9] Marczin N, Popov AF, Zych B, et al. Outcomes of minimally invasive lung transplantation in a single centre: the routine approach for the future or do we still need clamshell incision? Interact Cardiovasc Thorac Surg. 2016; 22: 537-545.

[10] Lang G, Czebe K, Gieszer B, et al. Lung transplantation program for Hungarian patients. [Tüdőtranszplantáció magyar betegek számára.] Orv Hetil. 2013; 154: 868-871. [Hungarian]

[11] Czebe K, Csiszér E, Lang G, et al. The first 12 years of history of Hungarian lung transplantations. [A tüdőtranszplantáció magyar történetének első 12 éve.] Orv Hetil. 2008; 149: 1635-1644. [Hungarian]
(Gieszer Balázs dr., Budapest, Ráth Gy. u. 7-9., 1122 e-mail: dr.gieszer@gmail.com)

A cikk a Creative Commons Attribution-NonCommercial 4.0 International License (https://creativecommons.org/licenses/by-nc/4.0) feltételei szerint publikált Open Access közlemény, melynek szellemében a cikk nem kereskedelmi célból bármilyen médiumban szabadon felhasználható, megosztható és újraközölhető, feltéve, hogy az eredeti szerző és a közlés helye, illetve a CC License linkje és az esetlegesen végrehajtott módosítások feltüntetésre kerülnek. 